\title{
Numbers and habitat of the Rapa Fruit- dove Ptilinopus huttoni
}

\author{
JEAN-CLAUDE THIBAULT and ALBERT VARNEY
}

\section{Summary}

A survey in December/January 1989/1990 revealed that an estimated 274 Rapa Fruit-doves Ptilinopus huttoni remain in Rapa's last (and fragmented) 292 ha of forest. This suggests no serious decline since 1974, but the forests continue to be degraded and cleared, and action to preserve key sites is urgently needed.

Un recensement en décembre/janvier 1989/1990 montra qu'un nombre estimé de 274 Ptilopes de Hutton Ptilinopus huttoni survivent dans les derniers 292 ha de forêt fragmentée sur l'île de Rapa. Ceci ne suggère aucun déclin important depuis 1974, mais les forêts continuent à être dégradées et coupées, ainsi il devient urgent d'entreprendre des actions pour le sauvegarde des sites clés.

\section{Introduction}

The Rapa Fruit-dove Ptilinopus huttoni is the only member of the pigeon family Columbidae found today on the island of Rapa, French Polynesia. It was first regarded as a threatened species in the 1970s (King 1978-1979) and continues to be mentioned in lists of birds threatened with extinction (Collar and Andrew 1988, Thibault 1988, Johnson and Stattersfield 1990). It is one of the rarest species of the modern Polynesian avifauna whose existence is threatened by a single, obvious problem: its forest habitat is regressing considerably. In this paper we propose to evaluate: (i) the area of forests available to the species and (ii) the number of birds remaining.

\section{Methods}

The island of Rapa $\left(27^{\circ} 37^{\prime} \mathrm{S} 144^{\circ} 20^{\prime} \mathrm{W}\right.$, Polynesia) is about $40 \mathrm{~km}^{2}$ in area. The highest point (Mt Perau) is at $650 \mathrm{~m}$; the average rainfall is $2,730 \mathrm{~mm}$ per year and the average temperature extremes are $17^{\circ} \mathrm{C}$ in August and $24^{\circ} \mathrm{C}$ in February.

Four types of vegetation are found in Rapa (Florence and Hallé 1986, Hallé 1986, Hallé and Florence 1986): (1) rainforests with numerous epiphytic mosses, situated between 450 and $650 \mathrm{~m}$ in altitude; (2) forests (remains of the tropical forest and secondary forests) rich in arborescent woods on the slopes of certain valleys and on the floor of the ridges; (3) wet grasslands and taros cultivation Colocasia esculenta found in the low alluvial plains; (4) fern Gleichenia and graminaceous Paspalum sp. "savannas" which developed instead of the forests as a result of fires and the presence of goats and cattle. 
We were in Rapa from 18 December 1989 until 6 January 1990 and visited most of the island. Counts were taken in 19 one-hectare plots of land and in eight plots that measured less than one hectare. The birds were located by sight or sound; the observation time was set at 30 minutes per plot, between o6hoo and 11 30 , which is the time of day when the birds are most active. The weather conditions were stable (no rain, and light or moderate wind). Because of the topography of the forest zones, we had good visibility of the sample plots from the ridges.

In order to calculate the area of the fruit-dove's habitat, a planimeter was used, based on a vegetation map (Hallé 1986) and modified by the observations we made, which confirmed the forest's regression.

We distinguished two types of wooded plot: on the one hand, forests where the tree cover is relatively homogeneous and close-knit and, on the other, forests which have a heterogeneous composition, including colonising species (Cyathea stokesii, Freycinetia arborea); dead "burned" trees are a sign of more or less ancient fires. Samples of the trees used by the birds were collected and determined by Jacques Florence (ORSTOM Centre, Pape'ete).

The historical references are mainly from Ernest Quayle's records (Whitney South Sea Expedition: American Museum of Natural History, New York), dating from his visit to Rapa on 14 to 20 April 1921 and on 15 to 26 February 1922 (Bryan ms). J.-C.T. was there from 15 October to 17 December 1974.

\section{Results}

\section{Distribution}

The distribution of the Rapa Fruit-dove corresponds to the category of "dominant wooded vegetation" on the island's vegetation map (Hallé 1986). Figure 1, established using this document, indicates the optimal distribution of the fruit-dove, and takes into account the zones occupied permanently and those visited only occasionally. The potential habitat extends over an area estimated at 292 ha, less than $8 \%$ of the island's total surface.

\section{Population estimate}

The density found in the 19 one-hectare plots varied between o and 2.3 individuals per ha. The mean density was 0.94 per ha $(\mathrm{SD}=0.69)$. The population estimate was 274 individuals $(175-368,95 \%$ confidence limits) for the 292 ha of forest.

\section{Habitat}

The fruit-dove lives exclusively in wooded areas from an altitude of 40 to about $450 \mathrm{~m}$. Birds visit all types of trees, including many species introduced by man, and which provide them with food. They occasionally visit the monospecific plantations of Pinus caribaea (one case of nesting has even been recorded from this habitat: Marc Liblin pers. comm.).

The birds prefer the most wooded areas: there was a very highly significant 


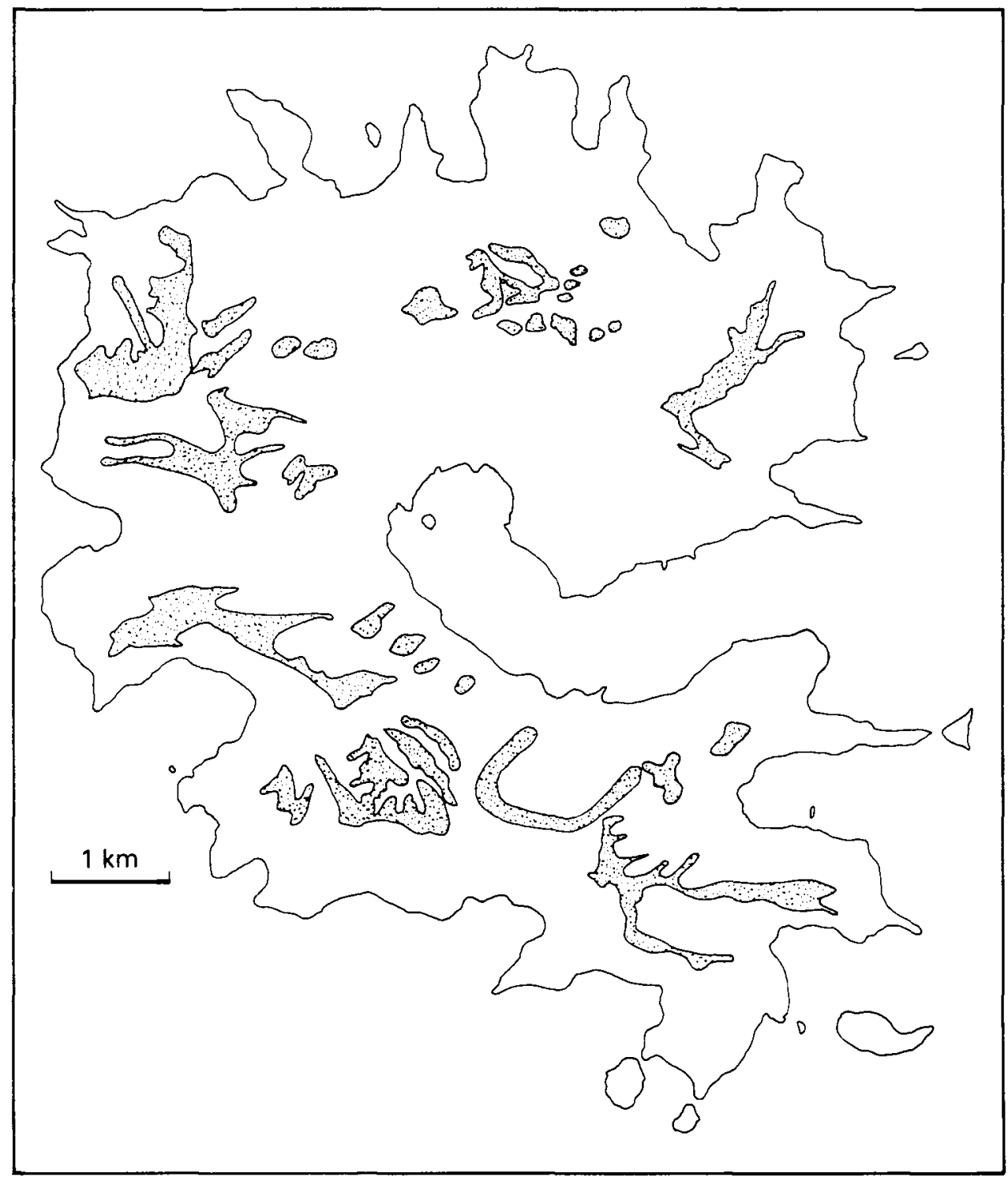

Figure 1. Map of the present-day suitable habitat of the Rapa Fruit-dove (shaded).

statistical difference in density ( $t$ test $\mathrm{P}<0.001$ ) between the plots situated in the forests with a covering of trees greater than $50 \%$ and those with a covering less than 50\% (especially with Cyathea and Freycinetia).

Generally, forest on Rapa today is considerably fragmented, and apart from eight patches whose area is over to ha each, the forest is made up of lots measuring a few hectares or even less than one hectare (see Figure 1 ). There is a very highly significant statistical difference between the average densities of fruit-doves in the plots whose area is less than one hectare and those in zones where the surface is more than one hectare $\left(\chi^{2}=28.9\right.$, d.f. $\left.=1, P<0.001\right)$; the very small isolated plots are visited less frequently than the bigger ones. 


\section{Diet}

There are many berry trees in Rapa's forests. The high productivity of these trees all year round has most certainly contributed to the survival of the fruit-dove. The types most visited and eaten by the birds during our stay were: Psidium guajava (Myrtaceae), Coffea arabica (Rubiaceae), Meryta choristantha (Araliaceae), Homalanthus stokesii (Euphorbiaceae), Corokia collenetti (Escalloniaceae), Oparanthus rapensis (Asteraceae) and Apetahia margaretae (Lobeliaceae). They possibly eat Freycinetia arborea (Pandanaceae). It also appears that they feed from the flowers (or nectar) of Metrocideros collina (Myrtaceae), a very common species but which was rarely in flower during our visit.

The birds eat while perching in the trees, by "picking" and "reaching", two of the three methods used by tropical fruit-eating birds (Moermond and Denslow 1985). They move heavily from branch to branch, examining the fruits before catching hold of them. Because of their relatively heavy weight ( 25 to $33 \%$ more than other fruit-doves from eastern Polynesia (Holyoak and Thibault 1978, 1984), they rarely move out to the end of the branches, but nevertheless they perform some contortions to obtain the fruit, for example turning their heads upside down.

\section{Discussion}

Because of the improvement in their standard of living, the local inhabitants have ceased hunting the fruit-dove. On the island there is a population of feral cats Felis catus, introduced before 1921 (Quayle ms), as well as Polynesian rats Rattus exulans, undoubtedly of some earlier origin, and it is possible that the birds are prey to these species. However, the density of fruit-doves in the smaller patches of forest suggests that the single main threat to the species is the regression of its habitat.

\section{Evolution of the population in the twentieth century}

There is no information concerning the nineteenth century, except for the unique specimen of unknown origin which allowed Finsch (1874) to describe the species. Hall (1869) does not mention pigeons in his brief list of birds in Rapa.

In April 1921 and February 1922, the members of the Whitney Expedition collected at least 22 specimens and thought that the species was not rare (Holyoak and Thibault 1984). However, careful reading of Ernest Quayle's (ms) journal suggests that the birds were not to be found in great numbers. His journal entries only mention a few daily contacts (observations or collections). During their first visit in April 1921, Rollo Beck and Quayle, assisted by other collectors, actively looked for the bird because it was missing from museum collections. But they only gathered 16 specimens in seven days, compared with more important collections of other species (e.g. 45 specimens of Scarletbreasted Lorikeet Vini kuhlii in nine days in Rimatara, and 73 specimens of Marquesas Ground-dove Gallicolumba rubescens in five days in Hatuta'a).

In October-December 1974, one of us (J.-C.T.), although not claiming to have made an exhaustive census, estimated that the population was 200-300 
individuals; it appears today that there is no decrease in population in the eight stations visited in 1974 and revisited in 1989-1990. After a visit in 1984, Pratt et al. (1987) indicated that the population could be less than 30 , but this estimate was probably based on a very limited survey of sites.

It is probable that the area of the fruit-dove's habitat has diminished during the twentieth century, along with a decrease in the population. However, we find it more relevant to speak in terms of a decline rather than a drastic decrease.

\section{Changes in habitat}

The earliest evidence of human life in Rapa can be traced back to at least the sixteenth century (Heyerdahl and Ferdon 1965). Land was cleared for traditional taro cultivation and the area involved was certainly as extensive as today. During the nineteenth century, goats and cattle were introduced to the island (Hall 1869). Their influence on the vegetation was considerable (grazing, mechanical action of the cattle). They encouraged the development of the fern Gleichenia linearis on the slopes and of the graminaceous Paspalum sp. which can now be found throughout the major part of the island. Because the livestock was very poorly exploited, their numbers increased greatly: 400-500 goats and 200 cattle in 1964, 5,000 goats and 500 cattle in 1980 (Paulay 1982), 6,000 goats and 600 cattle in 1989 (Marc Liblin pers. comm.). The inhabitants use fires to control the ferns, and sometimes the fires get out of hand and destroy parts of the forest. Using fires to clear land is an old tradition in Polynesia and most forests in Rapa show signs of ancient fires (burned trunks, dense growth of Cyathea); today, because of the presence of herbivores, the inhabitants tend to burn certain zones repeatedly and frequently, and the vegetation will not regenerate.

\section{The future of the fruit-dove}

Being an insular bird of considerable body-size, it is probable that the fruit-dove has a long life-span. On a short-term basis (within a decade), it is not really threatened with extinction. But it is a specialised species whose habitat is continually diminishing. It is clear that the forest's capacity for regeneration is remarkable, especially owing to abundant and perennial rainfall. Indeed, by transforming the extensive stock-farming (factor of fires and destruction of the vegetation) into intensive breeding in restricted areas chosen for soil quality (Trichet et al. 1986), the forest would be able to maintain itself and perhaps even regenerate in some areas. Such a step would mean a radical change in outlook and take a long time. In the meantime, short-term action has been proposed to the Rapa authorities (Municipality of Rapa) and to the Health, Research and Environment Ministry in French Polynesia, whereby the largest part of the forest (the Hiri Valley) would be fenced in and classified as a natural reserve. Taking into consideration the possible risks of disease (Cooper 1989) or a reduction in the population owing to the drastic loss of an important part of the forest to a cyclone, breeding in captivity is being considered. The species would therefore be protected from extinction for the time being.

In conclusion, because of its small population, but especially because of its 
deteriorating habitat, we advise that the Rapa Fruit-dove be maintained in the Red Data Book and that it be listed as "vulnerable".

\section{Acknowledgements}

This work was carried out on behalf of the Polynesian Ministry of Health, Scientific Research and Environment (FIRST no. 90/0008). We express our thanks to Jacques Florence, Marc Liblin, Claude Monnet and Philippe Siu for their help and encouragement in the organisation of the expedition, to Lionel Watanabé, Mayor of Rapa, for his welcome, to Dr Vincent Bretagnolle who improved the manuscript with his criticisms and to Dr Jean-Louis Martin (American Museum of Natural History, New York) who kindly made available the information concerning the Whitney South Sea Expedition to Rapa.

\section{References}

Bryan, E. H. Jr. (ms) Chronological summary and guide to the Whitney Expedition journals held in the American Museum of Natural History, New York.

Collar, N. J. and Andrew, P. (1988) Birds to watch: the ICBP world checklist of threatened birds. Cambridge, U.K.: International Council for Bird Preservation (Techn. Publ. 8).

Cooper, J. E. (1989) The role of pathogens in threatened populations: an historical review. Pp.51-61 in J. E. Cooper, ed. Disease and threatened birds. Cambridge, U.K.: International Council for Bird Preservation (Techn. Publ. 10).

Finsch, O. (1874) On a new species of fruit-pigeon from the Pacific Island of Rapa or Opara. Proc. Zool. Soc. London: 92-95.

Florence, J. and Hallé, N. (1986) Suite du catalogue des plantes à fleurs et fougères des îles Australes. Pp.151-158 in Rapa. Lefrancq, Candé: Direction des centres d'expérimentations nucléaires.

Goodwin, D. (1983) Pigeons and doves of the world. Third edition. London: British Museum (Natural History).

Hall, J. V. (1869) Description of the island of Rapa. Proc. Royal Geogr. Soc. 13: 84-91.

Hallé, N. (1986) Carte des forêts de l'île Rapa (Polynésie française); in Trichet, J., Jamet, R., Gautheyrou, J. Reconnaissance des sols et des altérations de l'île de Rapa. Pp.102103 in Rapa. Lefrancq, Candé: Direction des centres d'expérimentations nucléaires.

Hallé, N. and Florence, J. (1986) Description de 10 espèces rares de plantes à fleurs de l'île de Rapa (dont une Célastracée nouvelle). Pp.129-149 in Rapa. Lefrancq, Candé: Direction des centres d'expérimentations nucléaires.

Heyerdahl, T. and Ferdon, E. N. (1965) Reports of the Norwegian Archeological Expedition to Easter Island and the East Pacific 1955-56. Stockholm: House.

Holyoak, D. T. and Thibault, J.-C. (1978) Notes on the phylogeny, distribution and ecology of frugivorous pigeons in Polynesia. Emu 78: 201-206.

Holyoak, D. T. and Thibault, J.-C. (1984) Contribution à l'étude des oiseaux de Polynésie orientale. Mém. Mus. Natn. Hist. Nat. 127: 1-209.

Johnson, T. H. and Stattersfield, A. J. (1990) A global review of island endemic birds. Ibis 132: $167-180$.

King, W. B. (1978-1979) Red data book 2. Aves. Second edition. Morges, Switzerland: International Union for Conservation of Nature and Natural Resources.

Moermond, T. C. and Denslow, J. S. (1985) Neotropical avian frugivores: patterns of behavior, morphology, and nutrition, with consequences for fruit selection. Pp.865897 in P. A. Buckley, M. S. Foster, E. S. Morton, R. S. Ridgely and F. G. Buckley, eds. Neotropical ornithology. Washington, D.C.: American Ornithologists' Union. 
Paulay, G. (1982) Rapa Island and its weevils. Discovery 16: 25-31.

Pratt, H. D., Bruner, P. L. and Berrett, D. G. (1987) The birds of Hawaii and the tropical Pacific. Princeton: Princeton University Press.

Quayle, E. H. (ms) Journal of the Whitney South Sea Expedition. Vols. H \& I. Held in the American Museum of Natural History, New York.

Thibault, J.-C. (1988) Menaces et conservation des oiseaux de Polynésie française. Pp.87124 in J.-C. Thibault and I. Guyot, eds. Livre rouge des oiseaux menacés des régions françaises d'outre-mer. Saint-Cloud: Conseil International pour la Protection des Oiseaux ([ICBP] Monogr. 5).

Trichet, J., Jamet, R. and Gautheyrou, J. (1986) Reconnaissance des sols et des altérations de l'île de Rapa. Pp.75-103 in Rapa. Lefrancq, Candé: Direction des centres d'expérimentations nucléaires.

JEAN-CLAUDE THIBAULT

Antenne du Muséum National d'Histoire Naturelle et de l'Ecole Pratique des Hautes Etudes, Centre de l'Environnement, B.P.1013, Papetoai-Mo'orea, French Polynesia; (present address) Parc naturel régional de la Corse, B.P.417, F-20184 Ajaccio, France.

\section{ALBERT VARNEY}

Institut français de Recherche Scientifique pour le Développement en Coopération (ORSTOM), Centre de Tahiti, B.P.529, Pape'ete, Polynésie française. 